\section{Representações figurativas e suas possibilidades para compreender os limites entre o judaísmo e o cristianismo na Antiguidade Tardia}

\author{
Figurative representations and their possibilities to understand \\ the boundaries between Judaism and Christianity in Late \\ Antiquity
}

Silvia M. A. Siqueira*

Resumo: A análise histórico-religiosa das representações figurativas de diferentes ambientes religiosos - judeus e cristãos - permite aprofundar as reflexões sobre o uso da arte como linguagem convencional, simbólica e de fácil compreensão. Porém, estabelece as diferenças de modo sutil, não se distanciando do proselitismo religioso ao usar o patrimônio iconográfico próprio da Antiguidade Tardia, como pretendemos demonstrar nesse artigo.

Abstract: The historical and religious analysis of the figurative representations in different religious contexts - the Jews and the Christian ones - allows us to deepen the reflections about the use of art as a conventional, symbolic and easy-to-understand language. However, our study establishes the differences among all these uses in a subtle way, not forgetting the use of the iconographic heritage to proselytize as a characteristic of Late Antiquity, as we intend to show in this article.
Palavras-chave:

Imagens;

Antiguidade Tardia; Iconografia cristã; Iconografia judaica; Linguagem simbólica.

\section{Keywords:}

Images;

Late Antiquity; Christian iconography; Jewish iconography; Symbolic language.

\footnotetext{
* Professora Adjunta do curso de História e do Mestrado Acadêmico em História (MAHIS), da Universidade Estadual do Ceará (Uece). Seus interesses e pesquisas privilegiam as reflexões relacionadas à História das Religiões, especialmente o ambiente religioso e cultural da Antiguidade Tardia, com especial atenção para a História das Mulheres.
} 
$\mathrm{E}$ ste é um primeiro ensaio na tentativa de compreender a força da linguagem figurativa na Antiguidade Tardia, ${ }^{1}$ fruto das primeiras leituras de estudos desenvolvidos sobre a arte paleocristã, ${ }^{2}$ um tema muito rico e vasto com uma bibliografia significativa. Se alguém espera descobrir aqui uma revisão bibliográfica extensa e profunda, certamente não a encontrará. Aqui serão apresentadas definições de ordem geral com as discussões fundamentais que seguramente contribuem muito para a compreensão das fronteiras entre judeus e cristãos no Império Romano, especialmente porque ambas devem seus modelos e modo de compor à arte romana.

Sobre a arte romana temos dois pressupostos básicos: o primeiro é aquele de que a história da arte romana é entendida como uma contínua e recíproca troca de impulsos entre o centro e a periferia, de relevo histórico, narrativo de um fato de interesse público, de caráter civil ou militar. A celebração de uma guerra vitoriosa é argumento habitual da arte romana. Em um segundo momento, de predominância da ideia monárquica de "essência religiosa", os temas iconográficos oficiais possuem consonância com a mensagem ligada à natureza simbólica religiosa, com uma preferência pelos temas triunfais simbólicos.

Tentar delimitar as fronteiras entre o judaísmo e o cristianismo, em qualquer recorte temporal, não é tarefa fácil, não obstante afigurar-se como simples devido às supostas linhas demarcatórias. Limes, em latim, mais do que estabelecer o limite entre dois campos ou a fronteira, pode indicar também uma diferença tênue - uma sutilíssima diferença (quaedam perquam tenui limite). Apreender o sutil, o detalhe, a nuance requer instrumentos variados e aqui privilegia-se o uso das imagens em detrimento de textos escritos. Não apenas porque é comum a ideia segundo a qual as imagens comunicam aquilo que as palavras calam, mas especialmente por tratar-se de uma análise de duas grandes religiões monoteístas que encontram na palavra escrita sua legítima inscrição na história da salvação humana. Eleger as imagens, ou representações figurativas,

\footnotetext{
${ }^{1}$ Nenhum trabalho é concluído por uma única pessoa. Particularmente acredito que de modo direto ou indireto há sempre um conjunto, uma conjuntura que o possibilita. Ainda que a ajuda ultrapasse as coisas práticas e predomine o desejo de sucesso e crescimento, do apoio e do profundo querer o bem do outro. Agradeço profundamente minha família italiana Pasqua De Sanctis, Ennio Sanzi, Alessandra Carucci. Sou grata também a Raffaele Guerra, o anjo- príncipe.

2 Esse trabalho não seria possível sem a contribuição da Professoressa Maria Giovanna Muzj que em seu curso "Roma Cristiana", oferecido junto à Facoltá di Scienze Ecclesiastiche Orientali do Pontificio Istituto Orientale, me proporcionou uma nova visão da Antiguidade cristã a partir da arte composta nos primeiros seis séculos. Os conhecimentos adquiridos foram decisivos na minha formação intelectual. À minha caríssima magistra deixo aqui expressa minha gratidão.
} 
significa ainda considerar o contexto temporal e espacial em sua abrangência cultural, social e religiosa a partir da pluralidade e diversificação, construindo um quadro amplo cujo cenário é palco para diferentes agentes que atuam em uma dinâmica rede de relações, influenciando e sendo influenciados, dando e recebendo em um movimento de reciprocidade e da alteridade proporcionado pelo outro.

O material simbólico é um privilégio do campo religioso porque o símbolo é universal e cada religião, de acordo com a sua constituição histórica, cria e insere símbolos para dar significado à sua própria constituição e legitimação do seu repertório sagrado. Naturalmente que a História das Religiões constrói suas tramas sobre a pesquisa filológica documental, atenta à localização cronológica, geográfica, históricocultural dos fenômenos, das personagens, dos textos e dos processos históricos que esta procura (BIANCHI, 1970). Mas as representações figurativas podem ajudar a perceber algumas engrenagens que estabelecem diferenças, mesmo que tênues, a partir de uma linguagem simbólica comum veiculada pela arte.

Basta pensar nas primeiras imagens cristãs encontradas em catacumbas, sarcófagos e igrejas - elaboradas entre o III e o VI séculos d. C, em diferentes locais dos domínios de Roma -, para encontrarmos em ambientes cristão ou pagão diversas referências às narrativas do Antigo Testamento registradas repetidamente em imagens, como de Adão e Eva, de Abel e Caim, Manassés e Efraim, do profeta Habacuc, Jacó e Raquel, a fuga de Lot de Sodoma, Moisés, o sacrifício de Abraão, o profeta Miquéias, a ascensão de Elias no carro de fogo, a travessia do Mar Morto, Moisés e Araão, Sansão com Balaão, o profeta Jonas engolido pela baleia ou mesmo do caso de Susana entre os anciãos, ${ }^{3}$ Daniel entre os leões, Davi, Josué, Melquisedec, entre outras. Mesmo que o uso de imagens tenha sido proibido para os hebreus, eles também fizeram uso delas como recurso de identificação e reforço identitário nas mais diversas ocasiões. O nascimento das imagens cristãs é aproximado ao daquele da arte figurativa hebraica, que advém da época dos Severos (GRABAR, 1991).

Alguns problemas têm sido levantados quanto ao uso de imagens por parte dos historiadores, em especial em relação à questão da interpretação de representações figurativas, uma vez que o recurso a uma linguagem simbólica e suas respectivas interpretações configuram, de certa maneira, um terreno pouco explorado na

\footnotetext{
${ }^{3}$ Narrativa que consta no Livro de Daniel, capítulo 13.
} 
historiografia. No caso dos textos em línguas antigas e também da epigrafia, pouco a pouco as diferentes áreas do conhecimento criaram uma hermenêutica com o auxílio da gramática, que é geralmente aceita. Entretanto, no caso das imagens, ainda está em curso a composição de métodos apropriados para a semântica figurativa.

A tentativa de estabelecer um campo de estudos específico da linguagem simbólica, ou melhor, de uma semântica figurativa, tem se desenvolvido significativamente, sobretudo pelo reconhecimento de que a arte é um sintoma cultural, digamos, uma espécie de iluminação. Luz esta que permite compreender a mudança no modo de pensar e representar o pensamento e a concepção de mundo. Desse modo, entramos no campo da estética simbólica, valorizando a força da representação figurativa que provoca, sobretudo, movimento e dinamismo.

As relações entre o judaísmo e o cristianismo não ocorreram de modo uniforme e compassado, mas sim de maneira plural; no sentido de que não existe um ou outro em modelos fechados hermeticamente. Na Antiguidade Tardia encontramos duas religiões que atuam em um ambiente plural, religioso e filosófico. Os primeiros registros figurativos de ambas as religiões datam do final do II século e início do III. Época caracterizada pela desestabilização e grave crise dos domínios de Roma. As causas destas são inúmeras, são tanto razões internas quanto externas. Entretanto, de uma maneira ou outra, todas elas são intrínsecas ao controle e à administração imperial e, seguramente, à incapacidade, ou mesmo impossibilidade, de resolver as inúmeras contradições estruturais do domínio romano (MAZZARINO, 1974).

\section{Interpretações da Antiguidade Tardia sob o ponto de vista da arte}

O termo Antiguidade Tardia tem sido utilizado por historiadores para definir o período de transição do mundo antigo para o período medieval: ${ }^{4}$ o historiador Cameron (1995) concebe este período entre os séculos IV e o V d. C.; Marrou (1979) estabelece um arco cronológico maior, entre 200 d .C. e 600 d. C.; Jones (1973) situa suas reflexões entre 284 d.C. e 602 d.C.; Brown (1974) preferiu definir o período entre Marco Aurélio e Maomé. Enfim, cada definição segue a abordagem historiográfica escolhida. $O$

\footnotetext{
4 Há uma variação da definição do recorte temporal. Alguns intérpretes usam o recurso à mudança imperial entre o III e VI séculos d. C., ou o final do período severiano, de 193 d. C. a 235 d. C., ou a ascensão de Diocleciano, no ano $284 \mathrm{~d}$. C, ou, finalmente, até Justiniano, com a sua tentativa de Restauratio Imperii, entre os anos de 482 d. C. a 565 d. C..
} 
que há em comum é o reconhecimento de todos estes autores de que esta é uma época de transição, o que possibilita reflexões profundas. Nas palavras de Mazzarino:

La 'Spätantike', 'Tardo antico', di Roma (o anche, come tradizionalmente si é chiamata, il 'basso impero') é appunto l'etá in cui la societá classica entró in crisi, ed una rivoluzione ebbe luogo contro di essa. In uno stato come quello imperiale romano, fondato in larga parte sulla tradizione e sul privilegio (contemperato, per altro, dalla adlectio), una rivoluzione non puó non fare appello alle forze e agli uomini che sentono I'insufficienza delle istituzioni antiche (MAZZARINO, 1974, p. 75-6).

A crise, ou melhor, o Estado imperial romano cujas bases se mantinham sobre a tradição e o privilégio, não tiveram meios de se manter, possivelmente porque a suposta "tradição romana" não foi suficientemente capaz de perceber-se por meio da pluralidade e diversidade. Várias mudanças, inclusive na linguagem artística e na arquitetura, são produtos de um mundo em crise, situações de incerteza diante do futuro. Em especial, a alteração do repertório iconográfico da estética clássica helenista baseado no naturalismo. Esta técnica foi usada para compor idealizadamente "como as coisas se aparentam", distante de como elas realmente eram, com uma sobrevalorização da aparência idealizada em um modelo de perfeição. Como cada modo de pensar corresponde a uma estética, essa arte também mudava pari passu, não existindo espaço para a estética ideal e perfeita. Muitos estudiosos, calcados em uma concepção catastrófica e negativa do período de transição do mundo antigo para o mundo medieval, passaram a ver essa nova arte que surgia como uma degeneração da estética clássica (CARRIÈ, 2010). Outros autores, entretanto, pensam que do ponto de vista artístico é possível analisar alguns limites que foram se constituindo, já que reflexos das mudanças passaram a fazer parte da linguagem das artes plásticas, escultura e pintura.

\section{Bianchi Bandinelli e a arte romana da Antiguidade Tardia: "a dor de viver"}

A bibliografia concernente à arte romana é imensa. Bianchi Bandinelli, em seus estudos, não apenas faz uma análise profunda da linguagem artística, mas também revisa uma vasta historiografia sobre ela (BIANCHI BANDINELLI 2007; 1984; BIANCHI BANDINELLI, TORELLI, 1976; BIANCHI BANDINELLI: AUBOYER 1965; FERRARI, 1998; DE VECCHI: CERCHIARI, 1999). Sua análise nos faz entender que a arte figurativa romana 
raramente, ou quase nunca, é desinteressada, mas possui uma grande importância histórica. Esta arte se caracterizou, sobretudo, pela celebração de um indivíduo em relação ao Estado, quanto do próprio Estado, entendido como protagonista por meio dos ilustres imperadores, seja como entidade política e/ou cultural. Muito além da influência recebida da produção grega, a arte romana, no decorrer da história da Urbs e do orbis romanorum, exprimiu as profundas mudanças culturais e ideológicas com uma determinada linguagem figurativa.

A produção artística romana, a partir do século III d. C., apresentou alterações significativas em relação à tradição predominante à época. Naturalmente que quando uma maneira tradicional de pensar e conceber a forma no campo das artes figurativas (artes plásticas, pintura e escultura) sofre alterações ou inovações para uma nova linguagem, provoca tanto irritação como rejeição das práticas ancoradas no passado. Bianchi Bandinelli, Eggers e Coarelli (1965) assinalam que o terceiro século foi palco de uma das mais clamorosas rupturas da linguagem artística, ou melhor, que a mudança da forma helenística clássica, com o abandono do naturalismo e do racionalismo, assinalou, assim, o início de um novo modo de conceber a expressão artística, que se desenvolveu em várias fases com coerência interna, durante o milênio sucessivo. O elemento irracional que compareceu na linguagem artística romana já no final do período antonino se afirmou efetivamente neste século, e não deixou mais a arte europeia.

A mudança profunda, segundo os autores acima citados, foi muito mais em relação ao conteúdo do que à forma: o característico equilíbrio entre a intuição e a racionalidade, em que se fundamentava a transparência, o sentido terrestre sobrehumano da arte grega, que permanecerá entre todas as formas a experiência formal única. Mudou além dos princípios formais helenísticos com a violação da anatomia, o abandono do naturalismo e o relaxamento progressivo. Enfim, mudou no distanciamento da coesão formal que expressou o sentido profundo de organicidade das estruturas, típico da coesão realista antiga e, consequentemente, da predominância de tendências definidas como expressionistas. 
Fig. 1: Prisioneira bárbara

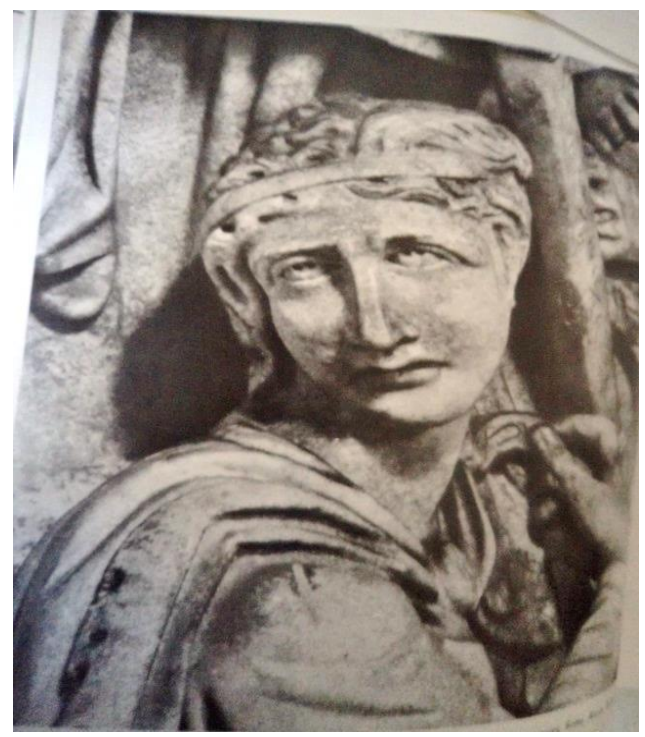

Roma. Sarcófago de um general de Marco Aurélio. Roma, Museu Nacional.
Fig. 2: Retrato do imperador Aécio

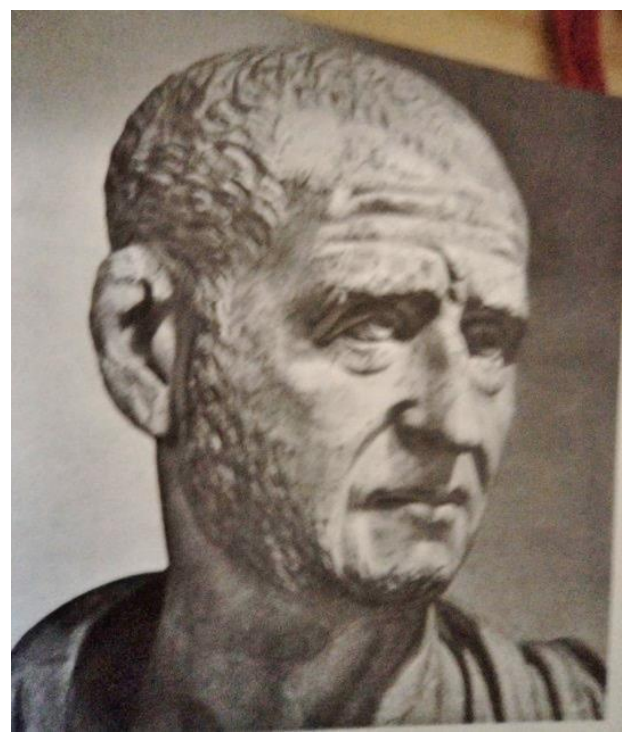

Roma, Museu Capitolino.

$\mathrm{Na}$ escultura, passam a ser utilizados recursos para exprimir a dor; não uma dor física, mas uma dor moral. Os retratos e bustos de caráter ornamental são elaborados de maneira a expressar uma angústia, utilizando-se como recurso expressivo o aumento dos olhos, além daquele usado pela norma naturalista, e nos olhos são acrescidas as pupilas e a íris ocular. Já a representação da figura do imperador mudou: daquela postura idealizada do herói viril e forte, como afirmação do poder, passa-se a uma feição angustiada e incerta. Bianchi Bandinelli define a arte como uma expressão específica e profunda da "dor de viver" e que o reflexo desse sofrimento está contido na arte por meio do esfacelamento da coesão orgânica, do valor dado à expressão e não à forma anatômica perfeita. Esse sofrimento, dolorido, é compreendido e explicado por meio da influência do pensamento de Plotino.

Explicar tamanha transformação só é possível se sairmos um pouco do âmbito "oficial" e ampliarmos a visão para os diferentes domínios da sociedade romana. Bandinelli faz ver que as mudanças da produção artística romana ocorreram a partir de uma dualidade, de um "bipolarismo": de lado, uma corrente de arte "patrícia" (ou áulica) e, de outro, uma corrente "plebeia" (ou popular). Ambas as correntes coexistiram desde o primeiro momento de constituição de uma arte romana, que em alguns períodos aproximaram-se e quase se fundiram e anularam-se. Entretanto, ambas as correntes artísticas conseguiram se manter, destacando-se no decorrer dos quatro séculos. Por 
um longo tempo, a corrente patrícia teve a vantagem, mas durante o século III e o início do IV, os elementos constitutivos e perenes da corrente plebeia começaram a fazer parte da linguagem figurativa romana, emergindo, assim, como expressão das profundas mudanças sociais e ideológicas daquele tempo. O rompimento com o naturalismo helenístico destitui aquela forma, que durante 800 anos perdurou e depois se afirmou de modo dominante na cultura artística da Antiguidade mediterrânea, irradiando-se muito além dela.

Bianchi Bandinelli reconhece na ruptura o início de uma nova periodização que ele denomina Antiguidade Tardia, indicação em senso estreito do fim do helenismo e o início, em ambiente romano, de um desenvolvimento formal novo que encontrará seu desenvolvimento lógico na arte da alta Idade Média, seja bizantina, seja "românica". O autor resolve o problema de expressões artísticas da Antiguidade Tardia e também indica o cruzamento das profundas transformações que germinaram no mundo oriental bizantino e no mundo ocidental medieval, fugindo da abordagem catastrófica relativa ao mundo antigo e procurando encontrar um desenvolvimento do processo histórico. Contudo, Bianchi Bandinelli, ainda que calcado na diversificação metodológica, se preocupou com a arte romana no centro do poder, ou seja, a própria Roma que usou com abundância a arte a serviço de uma ideologia de governo e deixou de abordar a complexa questão a partir das religiões. Essa tarefa ficou sob a responsabilidade de outro estudioso: André Grabar.

\section{André Grabar e a arte paleocristã: "os olhos do espírito"}

A análise específica voltada para a questão da arte cristã e também, em menor escala, da arte hebraica, é levada a cabo por outro estudioso da arte, André Grabar, o qual utiliza o termo "arte paleocristã" para demonstrar o emergir da iconografia com inspiração religiosa monoteísta. Este autor, que se apresenta como historiador da arte e não filósofo, contribuiu grandemente para a historiografia e para a filosofia. $O$ fato é que a sua afirmação de que "a arte cristã nasceu velha" causou um impacto significativo nos estudos relativos à arte. Ele defendeu, sobretudo, a iconografia cristã como a herdeira da tradição clássica do mundo mediterrâneo. A produção figurativa é produto de sua época e as artes plásticas cristãs foram elaboradas a partir da tradição 
predominante, com recursos e expressões pertencentes à linguagem geral das artes visuais e com as técnicas comumente praticadas no Império Romano do II ao IV séculos.

A iconografia cristã formou-se apenas dois séculos depois da formação da Cristandade, quando a religião já havia definido e propagado suas mensagens por meio de palavras. Os autores cristãos difundiram as mesmas expressões e significados de seus contemporâneos, seja em textos ou em imagens, assim como a linguagem verbal e visual do mundo greco-romano. Isso foi natural, mas ao mesmo tempo significou que mesmo sendo um argumento cristão, o modo de compor não foi cristão, ou melhor, foi aquele comumente utilizado. Assim, as imagens cristãs foram criadas para serem compreendidas por seus contemporâneos, cristãos ou não, e efetivamente alcançaram seus objetivos.

Em um primeiro momento, pode parecer algo sem importância o fato de os criadores (artesãos) desenvolverem o repertório cristão a partir daquilo que pertencia ao mundo cultural mediterrâneo. Entretanto, quando analisamos o contexto, é possível entender a formação de uma linguagem plural que poderia ser lida e entendida tanto por pagãos, judeus ou cristãos. Com poucas exceções de temas, a iconografia paleocristã não teve seus próprios termos. Não existiu uma linguagem própria, mas sim um modo parasita, incompleto, com um vocabulário especial e limitado. Assim sendo, houve uma linguagem iconográfica cristã que não compreendeu um repertório de signos apropriados para todos os possíveis usos, mas que consistiu em um grupo limitado de termos técnicos, os quais, quando acrescidos aos termos da imagética da época, deram às imagens a significação cristã.

Criou-se, assim, uma linguagem com termos emprestados e novas versões para esses termos que originalmente tinham uma definição e passaram a ter outros. Por exemplo, a figura do filósofo que originalmente tinha um lugar social na arte filosóficoreligiosa do Império. Os cristãos repetiam o tema, mas deram à imagem do filósofo uma linguagem iconográfica especial e novos valores, como o símbolo do Cristo, o "verdadeiro filósofo".

A criação da figura de Cristo foi elaborada a partir de uma tipologia de retrato que faz parte de um repertório usado no mundo antigo. Repertório configura-se como uma coleção ou um conjunto elaborado por matéria. Há vários repertórios: aquele do retrato coletivo, do filósofo, das sumas divindades, do poder, o repertório pastoral, mitológico, o retrato convencional de um bárbaro, dentre outros. Quando o artista 
usava um desses estilos do repertório, procurava ressaltar no retrato tipológico a natureza divina do Cristo. Assim, a partir de um molde, transmitia uma mensagem compreendida de modo unívoco aos diferentes espectadores (ZANKER, 2000; GRABAR, 2011).

A mudança estética da arte da Antiguidade Tardia daquela comumente usada no período medieval, segundo Grabar, foi de clara inspiração advinda do pensamento de Plotino, em especial no modo de contemplar uma obra de arte e o valor filosófico e religioso atribuído por ele à obra de arte. As imagens elaboradas em um primeiro plano e algumas como se fossem o avesso convidavam o espectador a usar os "olhos da alma". De modo que a imagem, mais do que imitar a aparência física em todos estes elementos, destacava os traços indispensáveis para a contemplação do "real" no modelo, fornecendo um conhecimento "total" ou, em outras palavras, fixando o resultado de uma visão do "inteligível". Enfim, uma tentativa de representar não a aparência física da obra posta diante do olhar, mas o resultado da contemplação que objetivava atingir os "olhos do espírito", a essência profunda da personagem representada.

Fig. 3: Filósofo

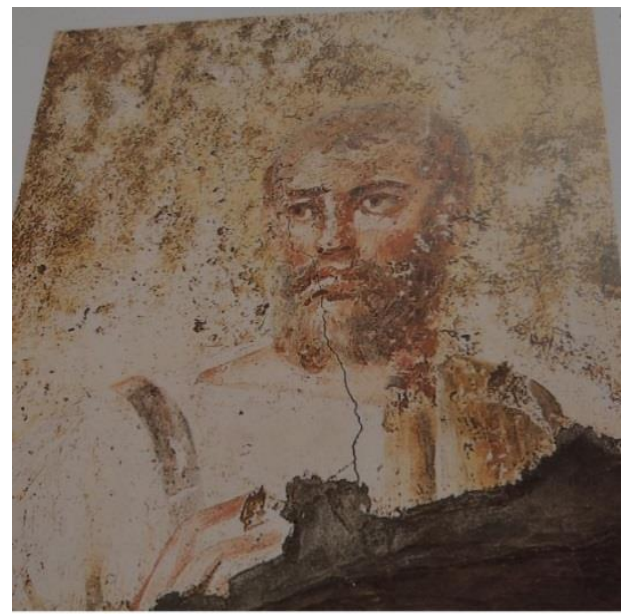

Hipogeu dos Aurélios, Viale Manzoni, Roma.
Fig. 4: Cristo

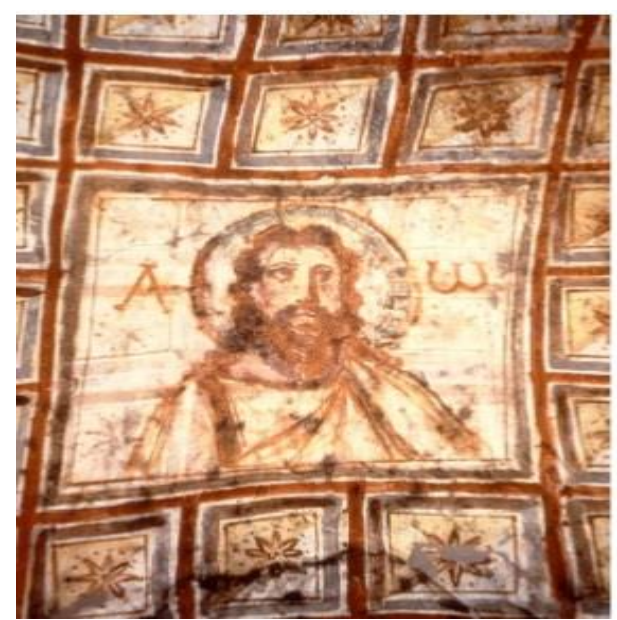

Catacumba de Comodila, Cubículo do Leão.

Do exposto até aqui, concluímos que tanto Bianchi Bandinelli quando Grabar procuram compreender a Antiguidade Tardia a partir do olhar da produção artística e filosófica, influenciada efetivamente pelo pensamento filosófico de Plotino. Se para o primeiro estudioso, a perspectiva filosófica é capaz de provocar uma aproximação dos sentimentos da elite romana, para o segundo ela antecipa algumas características do 
espectador medieval por meio das opiniões relativas à maneira de abordar a obra de arte, de questionar e apreciar cada visão, em particular a contemplação artística.

\section{Os limites entre judeus e cristãos na arte figurativa}

A produção artística elaborada seja por representantes do judaísmo ou do cristianismo esteve inserida num contexto de mudanças e declínio da forma clássica helenista, privilegiando um esforço por parte do espectador para a reflexão religiosa e o distanciamento da realidade material. Ambas tiveram a necessidade de se equilibrar neste quadro, cada qual à sua maneira, a partir de um imaginário coletivo mais amplo, no qual ainda predomina a religião oficial romana que convive, nem sempre de modo pacifico e harmônico, com diferentes expressões religiosas e tendências filosóficas.

Pensando na pluralidade e multiplicidade religiosa e cultural do mundo dominado por Roma, refletindo também sobre os diferentes caminhos tomados pelos artistas, é necessário compreendermos o ambiente dividido por diversos grupos: pagãos, cristãos, judeus. $E$, também, a linguagem simbólica e artística que responde a um uso padronizado do modo de composição, o qual conduz à chave iconográfica, permitindo, assim, a atuação do aparato simbólico de um grupo sobre outro grupo. Perceber a rede de interdependência e conexão entre estes grupos requer que um grupo reconheça o outro em seu campo de significado semântico e linguístico, isto é, das palavras (para a língua) ou dos temas (para a iconografia), que formam famílias semânticas, isto é, conjuntos de palavras e temas que foram usados para transmitir o seu próprio significado. Palavras de diferentes raízes e formas podem pertencer à mesma família semântica, por exemplo: conquistador, vitória, troféu, glória, dominação e suas correspondentes, derrota, prisioneiro, escravo, luta, caça, circo, entre outras. Em iconografia, as cenas de vitória nos combates, o troféu que é um símbolo de vitória, a coroa de louros, etc. Como as palavras no campo semântico da linguagem, os termos da comunicação imagética estão conectados com as palavras, não na forma, mas no significado argumentativo.

Imagens e palavras, a despeito das aparências, seguem o repertório cultural da Antiguidade Tardia. Por exemplo, no caso da ressurreição há inúmeras imagens que são diferentes entre si, mas representam o mesmo episódio e são marcadas por fórmulas iconográficas como aquela do triunfo, presente na imagética imperial. A iconografia da 
ressurreição é mostrada do mesmo modo que a iconografia do triunfo. O tema da salvação foi central no pensamento e na experiência de qualquer religião, já que ela foi a garantia de vida e o destino do indivíduo após a morte.

A arte dos monumentos funerários nas catacumbas e em sarcófagos compõe um tecido complexo combinado por diferentes temas iconográficos, tentando-se superar o medo e a tristeza da morte por meio de uma aparência vivaz, com figuras graciosas e atraentes e usando-se alegorias que reproduziam o esquema da arte convencional. De modo geral, as pinturas das catacumbas se limitaram a sugerir acontecimentos e não a descrevê-los, por meio de signos facilmente decifráveis e que não produziam equívocos. Grabar atenta para a disputa propagandista entre judeus e cristãos, por meio da confecção de representações figurativas, nas quais a imagem é elaborada com o objetivo de angariar novos prosélitos, especialmente no século III d. C. A iconografia judaica, particularmente, teve, em resposta a ela, a criação da iconografia cristã a partir de um recurso pertencente ao repertório de imagens que representam a vitória sobre a morte. Uma análise sobre as imagens constantes nas catacumbas cristãs, nos monumentos funerários e nos sarcófagos evidencia personagens específicas do Antigo Testamento, cuja ação de vida remete à superação, mediante a fé e à fidelidade a Deus, o que conduziu à ideia de vitória sobre a morte, como nas figuras a seguir:

Fig. 5: Daniel na cova dos leões

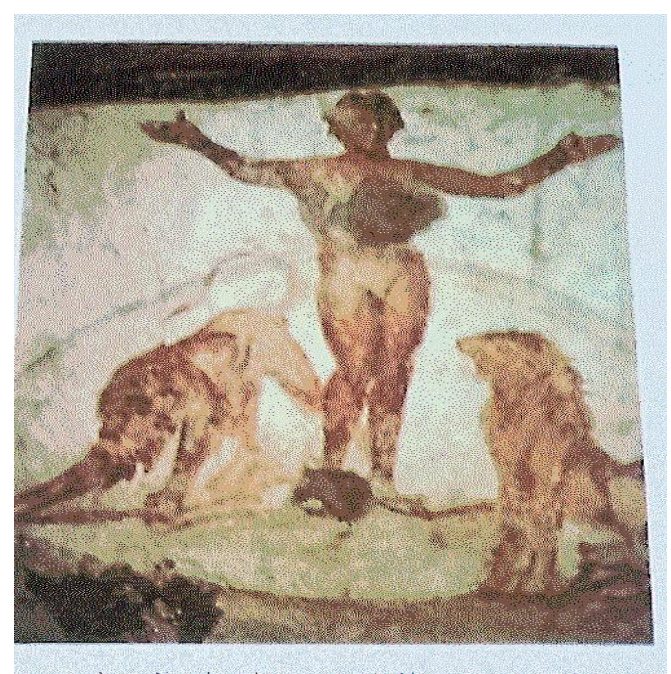

Catacumba da Via Anapo. Roma.
Fig. 6: Davi com a funda

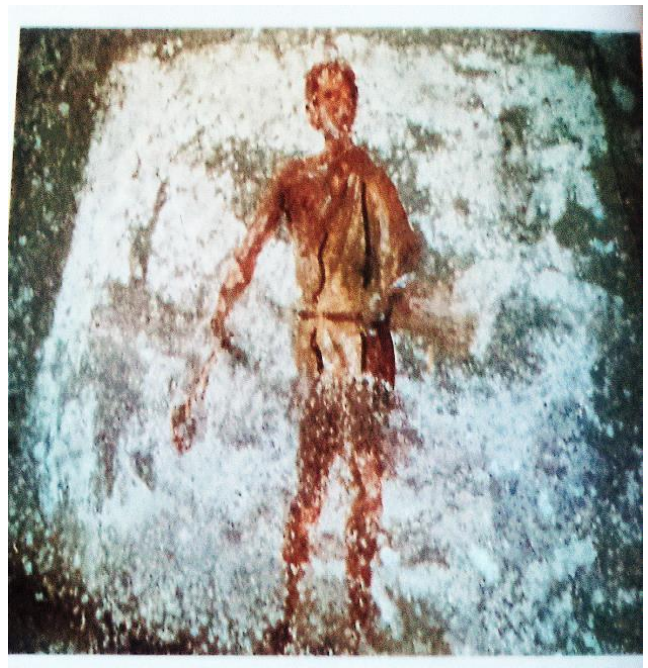

Catacumba de Domitila, Roma. 
A tradição hebraica usou muitas imagens para decorar objetos de uso comum, como xícaras, copos e taças pintadas e esculpidas ou, ainda, decoradas com folhas de ouro. Com uma abundância significativa de exemplos de hebreus, como Abraão, Noé, Davi, há imagens da criação hebraica e orações também hebraicas.

Um grande número de episódios que representam a salvação no Antigo Testamento são constantes em sarcófagos e, sobretudo, nas catacumbas, o que torna verossímil a contribuição hebraica para o cristianismo. Assim, um mesmo tema bíblico servia a dois propósitos distintos: os hebreus exploravam a salvação do povo eleito através das experiências do passado, enquanto que os cristãos pregavam a salvação individual após a morte, uma "guerra de propaganda" entre as duas religiões, travada por meio das imagens. Ao adotar determinado tipo de programa iconográfico, cada religião não apenas conservava seus fiéis, mas também fazia novos prosélitos.

Fig. 7: Jonas atirado ao mar

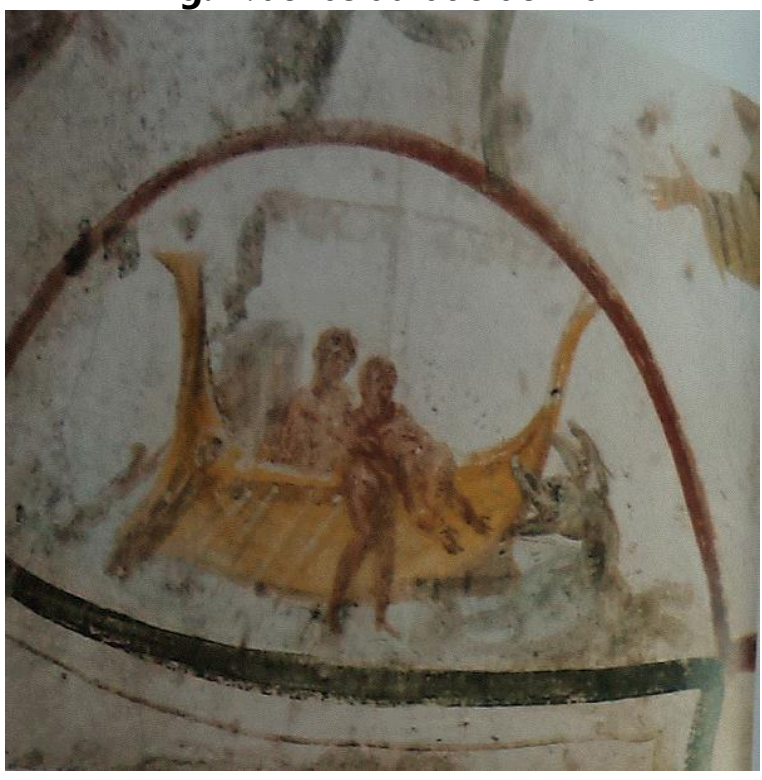

Catacumba dos santos Marcelino e Pietro.
Fig. 8: Noé e a pomba

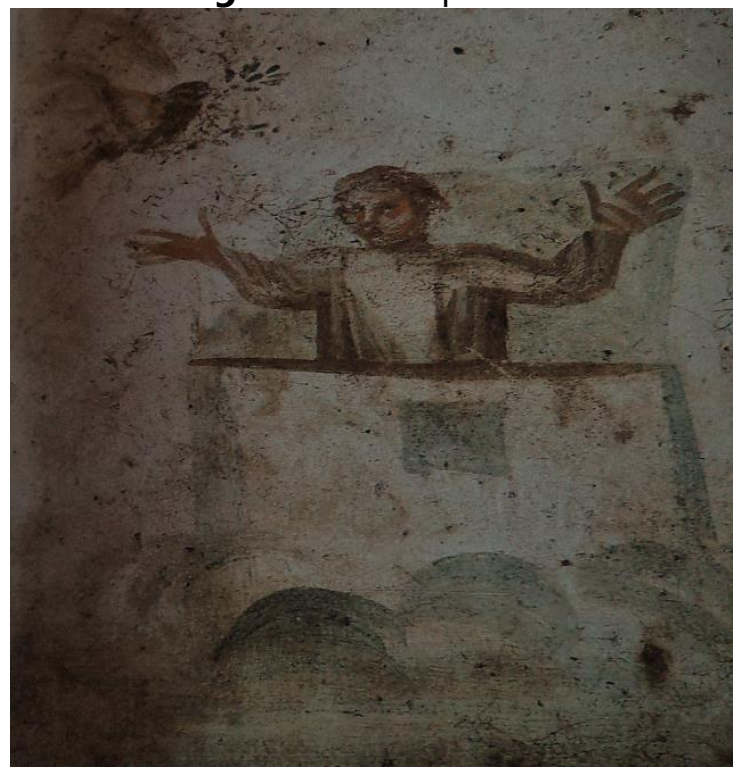

Catacumba dos santos Marcelino e Pietro.

Imagens como estas invocavam a mensagem contida na fórmula: "salva-me como salvou outros" comum na arte funerária. Os cristãos utilizaram com bastante inteligência um número limitado de figuras, não apenas de origem hebraica, mas também de origem pagã e criaram imagens alegóricas difusas entre o III e o IV séculos. Posteriormente, a iconografia cristã substitui os símbolos e as alegorias por representações concretas contidas nos retratos e efígies. Enfim, nas catacumbas mais antigas, a quase totalidade das imagens foi inspirada no Antigo Testamento, com 
predominância para a representação de personagens que superaram a morte, que eram evocados na esperança de se receber, como eles, a salvação.

Ainda nesse sentido, o exemplo contundente que fornece elementos tanto para o judaísmo como para o cristianismo é a arte de Dura-Europos. Esta cidade foi fundada por Seleuco I, no período helenístico; tornou-se cidade de fronteira da província romana conquistada por Trajano a partir de 165 e passou a ser praça militar dos confins romanos da província da Síria, base de partida para a guerra contra os partos. Foi reconquistada e destruída pelos persas sassânidas após 256 e, em 272 d. C, destruída e abandonada. Os estudos arqueológicos nessa cidade foram conduzidos pela Universidade de Yale entre os anos de 1921 e 1936 (BIANCHI BANDINELLI, 2012, p. $334)_{1}^{5}$ e são muito importantes, não apenas pelo conjunto da obra, mas pelo estado de preservação.

As primeiras imagens cristãs apareceram, aproximadamente, no ano 200 d. C. Já as pinturas de Dura-Europos são datadas em torno de $230 \mathrm{~d}$. C., enquanto que as primeiras imagens que constam dos monumentos hebraicos datam da primeira metade do século III. Parece que nesse momento é possível perceber a criação de uma iconografia religiosa judaica. Suas primeiras representações estiveram, de certa maneira, coligadas às primeiras criações cristãs. Ou seja, foram criações simbólicas, como os relevos da sinagoga de Cafarnaum, na Galileia; as moedas de Apameia, na Frígia, com a incisão do ciclo completo de Noé, que registram a atuação da comunidade judaica naquela cidade. Enfim, em Dura-Europos há registros cristãos e hebraicos bastante instigantes do ponto de vista artístico. Momigliano (1987) alerta para os vários problemas metodológicos oriundos das interpretações dos símbolos judeu-helenísticos. Múltiplas dificuldades se estabelecem por razões de espaço, tempo e de coexistência de tradições culturais diferentes. É grande a variedade da documentação, cujo arco temporal contempla cerca de oito a nove séculos, em áreas geográficas extensas que vão da Península Ibérica até a Mesopotâmia, muito ainda sem datação, sobretudo porque o conjunto de testemunhos, mesmo que a composição seja atribuída a judeus, é produto de grupos diversos que, do ponto de vista educacional, podem ser subdivididos em subgrupos que receberam educação diferenciada entre si. A pluralidade hebraica foi significativa, caracterizada pelo bilinguismo e, possivelmente,

\footnotetext{
${ }^{5}$ A Universidade disponibiliza em seu site a consulta e visita virtual à galeria de arte disponível em $<$ http://artgallery.yale.edu/duraeuropos $\angle$.
} 
pelo trilinguismo. O conhecimento literário, artístico e religioso implícitos no poliglotismo não é fácil de determinar, mas pode estar presente na variedade figurativa com a qual os hebreus decoraram suas tumbas, sinagogas e muitos objetos de uso comum.

Grabar se detém nas possíveis causas das semelhanças em ambos os projetos imagéticos. Mesmo que concorrentes e rivais, judeus e cristãos não eram impermeáveis às influências recíprocas, pois ambos têm origem comum. Ambos elegeram símbolos possíveis de serem reproduzidos isoladamente em qualquer lugar para proclamar a presença do culto. Por exemplo, no caso hebraico, o candelabro de sete braços do Templo, a estrela, a coroa, entre outros. Enquanto que no caso cristão, a pomba, a âncora, o peixe, o carneiro, etc. Enfim, os hebreus, da mesma maneira que os cristãos, sentiram a necessidade de criar imagens com conteúdo religioso, divulgando seus símbolos predominantes, como o Templo, a Arca, o Leão de Judá, a benção de Jacó às doze tribos de Israel, etc.

Resumindo, as representações de narrativas, nas quais o povo eleito é a encarnação do herói, se materializam num programa iconográfico onde os interesses religiosos do Povo de Israel no seu conjunto representam o passado e o porvir messiânico. Destacam-se, nas representações, a atitude de Deus em relação ao seu povo através dos séculos e o castigo infligido por ele aos inimigos dos eleitos e aos traidores. Enfim, pensando de modo geral, nada pode indicar melhor o judaísmo do que assimilar o Povo de Deus a Israel e à glória final de Deus para o reino messiânico de Judá sobre a terra.

Fig. 9: O templo e a arca

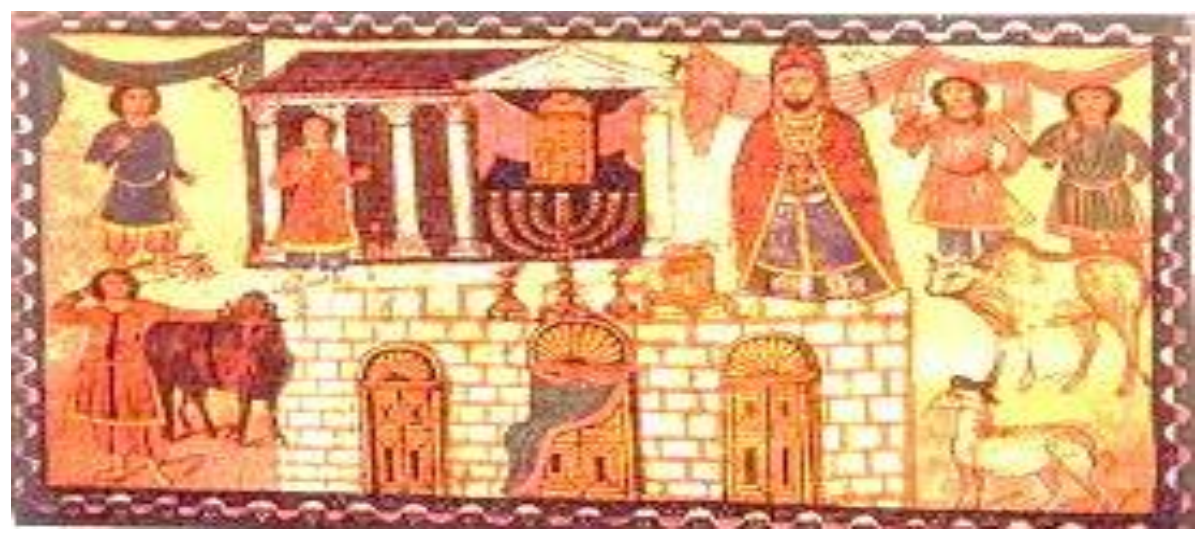

Sinagoga de Dura-Europos, Museu Nacional, Damasco. 
Outro aspecto em relação aos limites entre judaísmo e cristianismo a partir das imagens foi destacado por Muzj (1995), em seu minucioso trabalho sobre a obra de Grabar. Ao analisar a relação entre a arte imperial e a arte cristã, Muzj atribui um grande valor à concepção monárquica de essência religiosa. Isto posto, basta recordar que a arte romana, a partir do II século, foi essencialmente triunfal e, por motivos ideológicos, atribuiu grande valor às cenas simbólicas convencionais de vitória do imperador. Enfim, a ideologia imperial encorajava a ideia de triunfo, de vitória, de potência (poder), propostas como momento essencial da nova religião cristã, a representação do poder divino.

A arte imperial estava inscrita na iconografia antiga como uma linguagem em certa medida "polivalente", que podia ser adaptada para exprimir conteúdos ideológicos diversos, mas, simbolicamente afins pela importância que o conhecimento da expressão figurativa judaica ocupou no pensamento grabariano. Em especial, em relação aos afrescos da sinagoga de Dura-Europos, bastante familiares aos esquemas iconográficos da arte imperial e, também, em relação aos estudos histórico-religiosos relativos ao judaísmo helenístico. O uso de diferentes versões iconográficas baseadas na arte monárquica, ou seja, representando o soberano sentado no trono, de um mesmo argumento escatológico no painel central, indica o uso de diferentes versões bíblicas para compor os painéis. Ora, mesmo não usando a Septuaginta para a elaboração da pintura, é possível verificar ali a natureza religiosa e política da pintura que, no conjunto, representava o dominato, ao afirmar a soberania de Jahvé. O recurso é sempre reunir um conjunto de imagens que representam simbolicamente a grandeza monárquica absoluta. Assim, a arte oficial dos reinos helenísticos, por meio de imagens artísticas religiosas, fixava fórmulas iconográficas.

Fig. 10: O triunfo de Mardoqueu

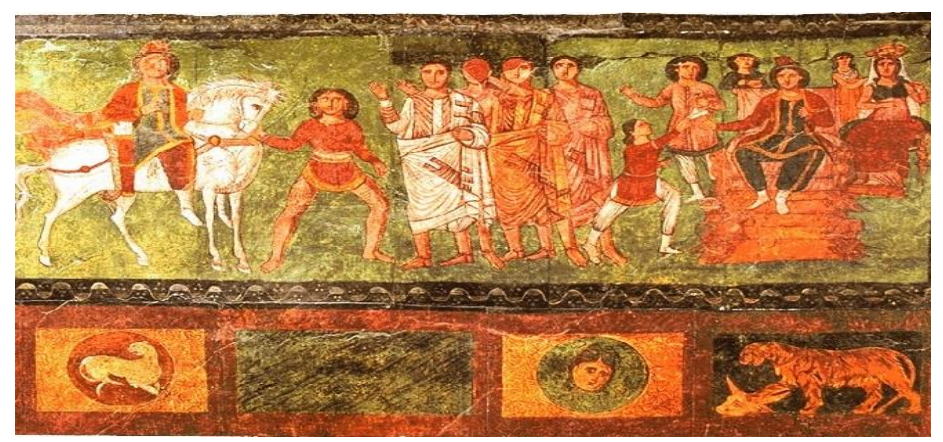

Dura-Europos, Museu Nacional de Damasco. 


\section{Considerações finais}

O Mundo Antigo fez um largo uso da imagem como recurso, mas os repertórios que exprimiam diversas mensagens religiosas caracterizavam-se por certa homogeneidade. Mesmo com diferentes abordagens religiosas - pagã, cristã, hebraica - todos elas faziam uso do mesmo recurso linguístico, ou melhor, da linguagem iconográfica do classicismo grego, com pequenas diferenças nos detalhes. É o grande tema da koiné da linguagem figurativa no mundo antigo. Esta, além de estar ancorada em uma definição do divino, tem uma expressão simbólica fundamentalmente unitária.

O principal motivo pelo qual a arte romana pode servir de modelo para a representação hebraica e cristã consiste no fato de que não havia ali uma oposição entre arte profana e arte religiosa, mas sim uma linguagem de natureza ideológicoreligiosa. Usando recursos e fórmulas iconográficas com apelos simbólicos conduzia-se o espectador para a apreensão da realidade inteligível, como a majestade, a potência, a ordem, a inalterabilidade e, finalmente, a natureza divina do imperador e seu poder, o que facilitava a passagem de uma realidade fenomenológica e material (imperador e vitória) para a realidade numênica, suprassensível, absoluta: o imperador como manifestação de Deus, ou melhor, como lugar de manifestação de Deus; a vitória como atributo do poder de origem divina, conceitos ideais como majestade, soberania, poder, e os mesmos conceitos absolutos atribuídos a Jahvé e à pessoa de Jesus Cristo, Verbo encarnado, Rei Universal, Salvador. Existindo, assim, um processo de intercâmbio dos esquemas simbólicos próprios da soberania, que em última instância são favorecidos pela homogeneidade de fundo da linguagem iconográfica antiga.

\section{Referências}

BERTI, S. Pagine ebraiche. Torino: Giulio Einaudi editore, 1987, p. 53-62.

BIANCHI BANDINELLI, R. Roma. La fine dell'arte antica. Milano: BUR, 2007. BIANCHI BANDINELLI, R. Roma. La fine dell'arte antica. Milano: BUR, 2012. . Il problema del ritratto. In: . L'arte classica. Roma: Editori Riuniti, 1984.

BIANCHI BANDINELLI, R.; AUBOYER, J. Ritratto. In: Enciclopedia dell'arte antica. Torino: UTET, 1965. 
BIANCHI BANDINELLI, R.; EGGERS, H.J.; COARELLI, F. Arte romana e commercio artistico oltre i confini. Roma: Istituto della Enciclopedia Italiana, 1965.

BIANCHI BANDINELLI, R.; TORELLI, M. L'arte dell'antichità classica. Torino: UTET, 1976.

BIANCHI, H. La storia delle religioni In: Storia delle religioni. Ed. UTET: Torino, p. 3-52, 1970. v. 1.

BISCONTI, F. Temi di iconografia paleocristiana. Cittá del Vaticano: Pontificio Istituto di archeologia cristiana, 2000.

BISCONTI, F.; FIOCCHI NICOLAI, V.; Mazzoleni, D. Le catacombe cristiane di Roma: origini, sviluppo, apparati decorativi, documentazione epigráfica. Regensburg: Schnell \& Steiner, 1998.

BOWERSOCK, G. W.; BROWN, P.; GRABAR, O. (eds.). Late Antiquity: a guide to the postclassical world. Cambridge: Harvard University Press, 1999.

BROWN, P. Il mondo Tardo Antico. Da Marco Aurelio a Maometto. Torino: Einaudi, 1974.

CAMERON, A. Il tardo impero romano. Bologna: Il Mulino, 1995.

CARRIÉ. J-M. Elitismo cultural e "democratização da cultura" no Império Romano Tardio. História, São Paulo, v. 29, p. 1-17, 2010.

CHAMPEAUX, G. De; STERCKX, S. Simboli de medioevo. Milano: Jaca Book, 1997.

DE VECCHI, P.; CERCHIARI, E. I tempi dell'arte. Milano: Bompiani, 1998, v. 1.

FERRARI, S. La psicologia del ritratto nell'arte e nella letteratura. Laterza: Bari-Roma 1998.

GRABAR, A. Le vie dell'Iconografia cristiana. Antichità e medioevo. Milano: Jaca Book, 2011. . Le origini dell'estetica medievale. Milano: Jaca Book, 2001. . L'arte Paleocristiana 200-395. 2a edizione italiana. Milano: Rizzoli, 1991. - Christian iconography: a study of its origins. Bollingen Series XXXV.10. New Jersey: Princeton University Press, 1980.

JONES, A. H. M. Il tardo impero romano. 284-602 d.C.. Milano: Il Saggiatore, 1973.

MARROU, H-I. Decadenza romana o tarda antichità? III-IV secolo. Milano: Jaca Book, 1979.

MAZZARINO, S. L'Impero romano 2. Roma: Editori Laterza. 2010. Il Basso Impero: antico, tardoantico ed èra costantiniana. Bari: Edizione Dedalo 1974. v. 1 e 2. 
MOMIGLIANO, A. Problemi di método nella interpretazione dei simboli giudeoellenistici In: MUZJ, M. G. Visione e presenza. Iconografia e teofania nel pensiero de André Grabar. Milano: La Casa di Matriona, 1995.

RUTGERS, L. V. Subterranean Rome: in search of the roots of Christianity in the catacombs of the Eternal. Leuven: Peeters, 2000.

__ The Jews in Late Ancient Rome. Evidence of cultural interaction in the Roman diaspora. Leiden, 1995.

WATAGHIN, G. C. I primi cristiani, tra imagines, historiae e pictura. Spunti di riflessione. Antiquité Tardive, v. 19, p.13-34, 2011.

ZANKER, P. Dal culto della paideia alla visione di Dio. In: Aurea Roma. Roma: Catalogo L'Erma, 2000, p. 407-412. 